\title{
The geological significance of Majstorska Cesta - a historical road on Velebit Mt. with a special review of Jurassic carbonate rocks
}

Rudarsko-geološko-naftni zbornik

(The Mining-Geology-Petroleum Engineering Bulletin) UDC: $551.7: 551.8$

DOI: $10.17794 / \mathrm{rgn} .2020 .3 \cdot 5$

Review scientific paper

\author{
Ivo Velićc ${ }^{1,3}$; Josipa Velićn ${ }^{2,3}$ \\ ${ }^{1}$ Croatian Geological Survey, Sachsova 2, 10000 Zagreb, Croatia \\ ${ }^{2}$ Faculty of Mining, Geology and Petroleum Engineering, University of Zagreb, Pierottijeva 6, 10000 Zagreb, Croatia; \\ ${ }^{3}$ Croatian Geological Summer School, Pančićeva 5, 10000 Zagreb, Croatia
}

\begin{abstract}
Majstorska Cesta is a historical road along Velebit Mt., NW of Sveti Rok, preserved in its original state since opening in 1832 and therefore added to the cultural heritage list of the Republic of Croatia in 2007. The road passes through sedimentary rocks ranging in age from Upper Carboniferous to Upper Paleogene, i.e. from 315 Ma until approx. 25 Ma old rocks (a time span of $290 \mathrm{Ma}$ ). These are mostly well exposed limestones and dolomites, sporadically clastics. Such rocks build up not only Velebit Mt., but also the entire Karst Dinarides. As such, they represent a unique natural museum important not only for the Croatian landscape, but also for all countries with shallow marine carbonates in the Mediterranean Region and wider, i.e. areas of Mexico, the Caribbean, along mountains like the Atlas, the Pyreneans, the Alps, the Carpathians, the Dinarides, the Helenides, the Pontides, the Taurides, the Iranides and the Himalayas. The most important geological feature is a section from Mali Alan Saddle to Tulove Grede Ridge. It is a continuous section along the Jurassic carbonates, typical for the Karst Dinarides, of stratigraphic period from Hettangian to Middle Tithonian (201.3-148 $\mathrm{Ma}$ ), comprising the typical (index) fossils and complete geological rock sections, including contact between Jurassic and Triassic rocks. The authors have researched Velebit Mt. since 1962 until recent times, and thus recognize the necessity to preserve the described Jurassic rock outcrops. They describe the geology of Majstorska Cesta from Sv. Rok to Obrovac.
\end{abstract}

\section{Key words:}

stratigraphy, carbonates, Jurassic, Majstorska Cesta, Velebit Mt, Karst Dinarides, Croatia

\section{Introduction}

Majstorska Cesta on Velebit Mt., connects Sv. Rok and Obrovac. It is protected as a natural monument, according to Croatian legislature. The road has been built over Upper Carboniferous, Middle and Upper Permian, Triassic, Jurassic, Cretaceous, Palaeogene and Quaternary rocks. The outcrops of Jurassic carbonates between Mali Alan Saddle and Tulove Grede Ridge are especially important, because they are of unique and scientifically important value in Croatia as well as worldwide.

The road transversely crosses almost a completely Jurassic sequence (201.3-148 Ma). It offers an exceptional view into the geological history of the Karst Dinarides, particularly the fossiliferous Jurassic rocks, comprising index fossils for a complete stratigraphic span, including contact with Triassic as well as Cretaceous and Palaeogene rocks. The Velebit Mt. Jurassic rocks were deposited on the Adriatic Carbonate Platform (AdCP; Vlahović et al., 2005), which existed during the Meso-

Corresponding author: Ivo Velić

ivo.velic@zg.t-com.hr zoic Era over the area of the present-day Karst Dinarides. It comprises carbonate sequences of total thickness between 6 and $12 \mathrm{~km}$. The size and age of the AdCP define it as a remarkable geological phenomenon in the world, which is continuously scientifically researched. Therefore, it is very important to preserve such localities and outcrops, keeping the evidence of the AdCP evolution intact.

With respect to the fact that Majstorska Cesta is already protected as tangible cultural heritage (under the category of protected cultural property), the exposed geological heritage can represent additional value for visitors. Such heritage must be described, explained and presented to the public in handbooks, informative pamphlets and signs.

The announcement of the renewal of this locality impelled us to prepare this review. This paper recommends that the representative and exceptional geological outcrops, from the Upper Palaeozoic to Mesozoic and Cainozoic, should be evaluated and considered as a part of national geological heritage. In that case, they would be preserved during the road reconstruction and presented to visitors on informative signs along the road. In this 
way, visitors could also use this road as an educational trail. Visitors of the Nature Park would be able to appreciate interesting and informative descriptions of the particular sites and sections, beautiful viewpoints and geological history of Velebit Mt. and the Croatian karst.

\section{History}

Majstorska Cesta had been planned with the purpose to shorten the voyage from Vienna, as a capital and land-

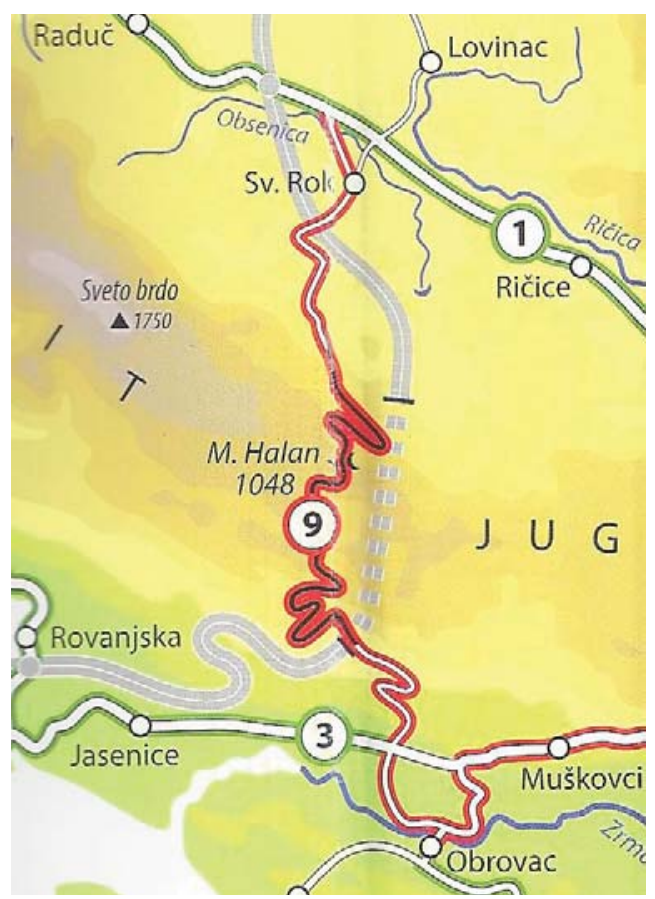

Figure 1: A geographic sketch map of the Majstorska Cesta location (after Cernički \& Forenbaher, 2o16; legend: 1 = Dalmatina Road, 3 = Obrovac roundabout and road toward Jesenice, 9 = Majstorska Cesta) locked part of the Austro-Hungary monarchy, to Dalmatia and its administrative centre Zadar. The construction of that trans-Velebit road started in 1825, from Obrovac to Tulove Grede, crossing the Alan Depression, Mali Alan Saddle towards Sveti Rok. Frontier officer Josip Kajetan Knežić, the famous builder of mountain roads, prepared the first independent project and construction works.

The road is $41 \mathrm{~km}$ long. It was completed in 1832 and named Majstorska Cesta (= Craftsman Road). The name reflects the way in which Knežić built the road across the steep Velebit Mt. slopes, with numerous serpentines, among canyons and gulches, which represented great progress in road construction for that time. The maximal road dip was up to $5.5 \%$, corresponding to current rules for road building (Cernički and Forenbaher, 2016). That new Velebit transversal had been used for trade and postal traffic between Vienna and Zadar, which lasted until the early 60 's of the $20^{\text {th }}$ century, i.e. until the opening of the Jadran Highway (Jadranska magistrala), and later the Lika Highway (Lička magistrala) connecting Gračac, Bruvno, Udbina and Plitvička jezera. Majstorska Cesta passes near the geomorphologically famous feature Tulove Grede Ridge, which is composed of vertical carbonate plates, beams and pillars as well as the attractive Alan Depression.

Majstorska cesta is a historical Velebit pathway (see Figure 1) and that is the reason it was included on the list of cultural heritage of the Republic of Croatia in 2007. Its main value is the fact that the road has been preserved since 1832 with its original route from the Paljenik locality (see Figure 2a, b) on the NW point of Sveti Rok to Obrovac (see Figure 3). Its cuttings and outcrops comprise the rocks of very wide stratigraphic range, from Upper Palaeozoic to Lower Cainozoic (i.e. Upper Carboniferous to Upper Palaeogene; 315 to 25 $\mathrm{Ma}, 290 \mathrm{Ma}$ in total). Thus, the deposits along the road
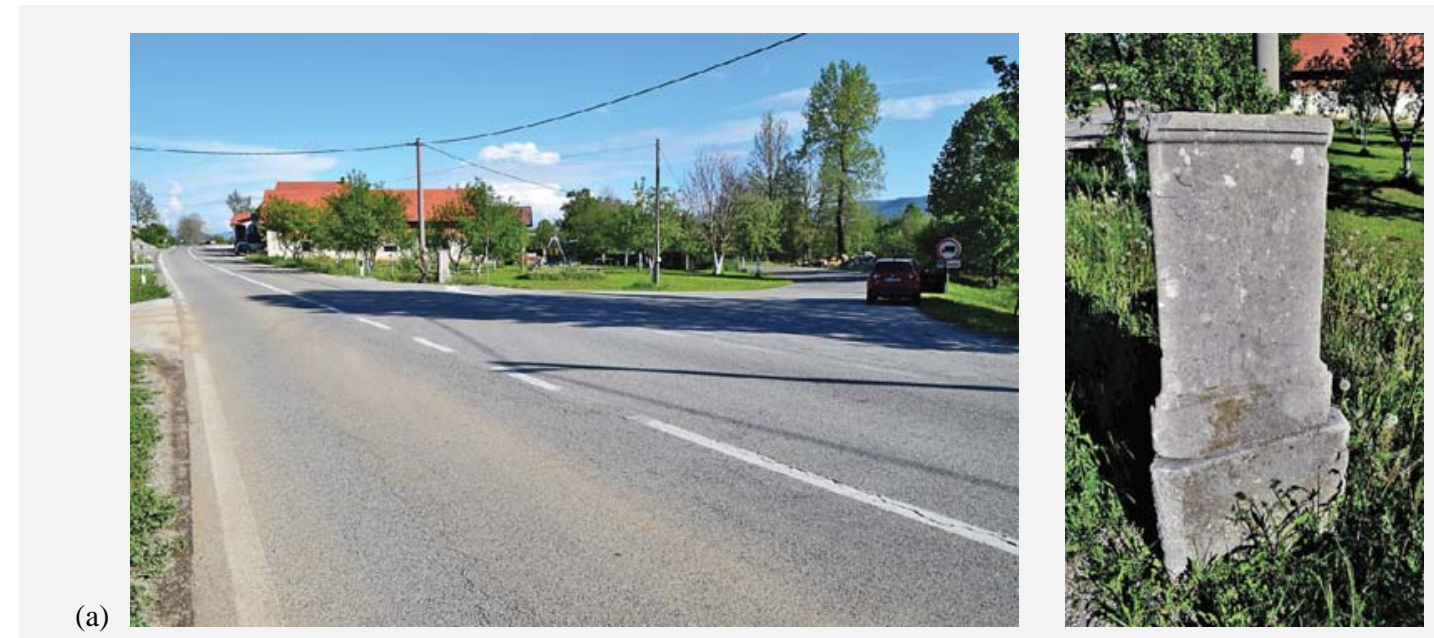

(b)

Figure 2: The start of Majstorska Cesta in Sv. Rok, on the crossroad with Dalmatina Road (a) and the original milestone from the $30^{\prime}$ s in the $19^{\text {th }}$ century (b) 
represent a natural geological museum of carbonates of the Dinaric Karst. The road was built from Obrovac to Sveti Rok, but the geological review in this paper runs in the opposite direction, thus respecting the rule that the oldest rocks are the first to be described. Figures $\mathbf{4}$ and $\mathbf{5}$ present the parts of the Basic Geological Maps of SFRY (1:100000), Obrovac (Ivanović et al., 1973) and Udbina (Šušnjar et al., 1973) sheets, with selected parts of the geological maps of Lika and Velebit where the road was constructed.

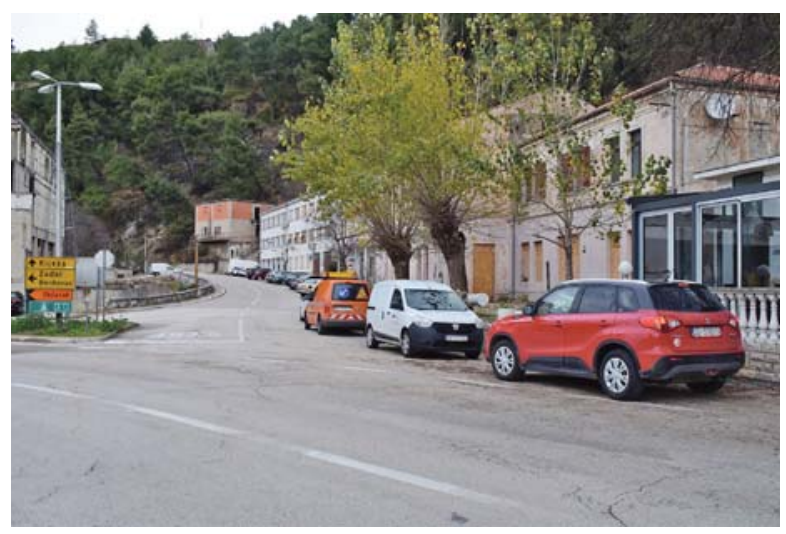

Figure 3: Toward the geological point near Majstorska Cesta in Obrovac, along the bridge on the $\mathrm{E}$ (right) bank of the Zrmanja River
The first important geological research on Majstorska Cesta and the surrounding area took place in the $1^{\text {st }} \mathrm{dec}-$ ade of the $20^{\text {th }}$ century, with data presented on geological map sheets Medak - Sv. Rok (Koch, 1909a; Schubert, 1909a, 1909b) and their explanatory books (Koch, 1909b, Schubert, 1910). Since that time, until the research for the Basic Geological Map of SFRY 1:100000, i.e. for seven decades, no significant explorations had been recorded.

Nikler and Sokač (1968) published the biostratigraphical data from Velebit Mt. and Jelaska and Velić (1971) described the lithostratigraphy of the Lower Jurassic deposits exposed along the road. During the explorations for the Basic Geological Map, the sheets Udbina (Šušnjar et al., 1973) and Obrovac (Ivanović et al., 1973), as well as their explanatory books (Sokač et al., 1976 for Udbina; Ivanović et al., 1976 for Obrovac) were published.

Some valuable data was published in the guidebook of the $9^{\text {th }}$ International symposium on fossil algae (Grgasović \& Vlahović, eds., 2007) on Majstorska Cesta, where in the introduction Velić (2007a) described geological characteristics of Velebit Mt. Grgasović and Sokač (2007) presented Permian Mizzia Dolomites (Micijski dolomiti) in Sv. Rok, Grgasović (2007) Ladinian Diplopora Limestones, Sokač (2007a) Lower Jurassic with algae Palaeodsycladus, Velić $(\mathbf{2 0 0 7 a}, \mathbf{b}, \mathbf{c )}$ Lower Jurassic Orbitopsella Limestones, Lithiotis Lime-

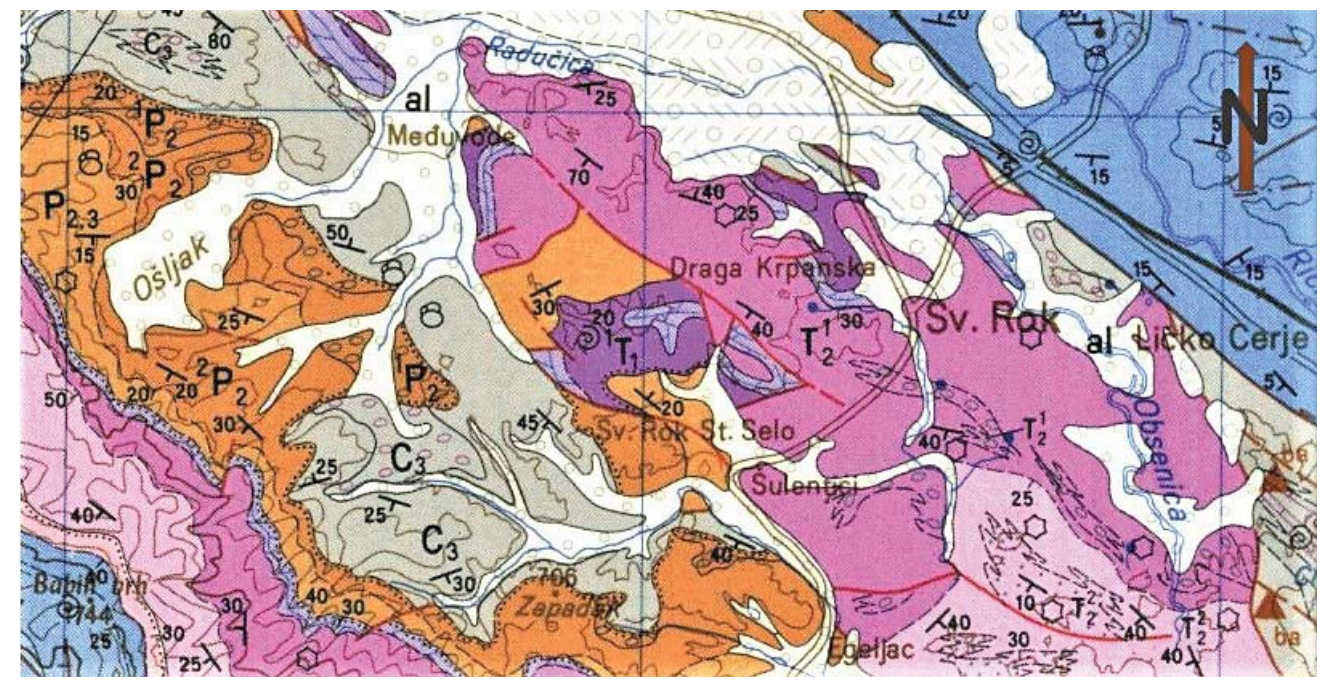

Figure 4: A part of the Basic Geological Map of SFRY 1:10oooo, Udbina sheet (Šušnjar i dr., 1973) with a section of Majstorska Cesta in Sv. Rok; legend (for Fig. 4 and Fig. 5): $\mathbf{C}_{3}=$ shales, sandstones, conglomerates and limestones, Upper Carboniferous; ${ }^{1} \mathbf{P}_{2}=$ conglomerates, Middle Permian; ${ }^{2} \mathbf{P}_{2}=$ Brušane sandstones, Middle Permian; $\mathbf{P}_{2,3}=$ Mizzia dolomites, Middle and Upper

${ }^{2}$ Permian: ${ }^{1} \mathbf{T}=$ sandy dolomites and micaceous sandstones, Lower Triassic; $\mathbf{T}_{2}{ }^{1}=$ Diplopora limestones, Middle Triassic,

Anisian; $\mathbf{T}_{2}{ }^{2}=$ Diplopora limestones with lenses of tuffitic siltites, Middle Triassic, Landinian; $\mathbf{T}_{3}{ }^{1,2}=$ Raibl siltstones, sandstones and conglomerates, Upper Triassic, Carnian and Norian; $\mathbf{T}_{3}^{2,3}=$ Main dolomite (Hauptdolomit), Upper Triassic, Norian and Rhaetian; $\mathbf{J}_{\mathbf{1}}=$ Mali Alan, Lithiotid and Spotted limestones with dolomite intercalations, Lower Jurassic; $\mathbf{J}_{2}=$ Alan limestones with dolomite intercalations, Middle Jurassic; $\mathbf{J}_{3}{ }_{3}^{1,2}=$ Alanac limestones and dolomites, Upper Jurassic, Oxfordian and Kimmeridgian; $\mathbf{J}_{3}^{2,3}=$ Clypeina limestones with dolomite intercalations, Upper Jurassic, Kimmeridgian and Tithonian; $\mathbf{K}_{1,2}=$ Limestones, dolomites and dolomite breccias, Lower and Upper Cretaceous; $\mathbf{K}_{2}^{1,2}=$ Rudist limestones and dolomites,

Upper Cretaceous, Cenomanian and Turonian; Pg,Ng = Velebit breccia and Promina conglomerates, Palaeogene and Neogene; $\mathbf{p r}=$ proluvial gravels and sands; $\mathbf{a l}=$ alluvial deposits; $\mathbf{b}=$ pond deposits 


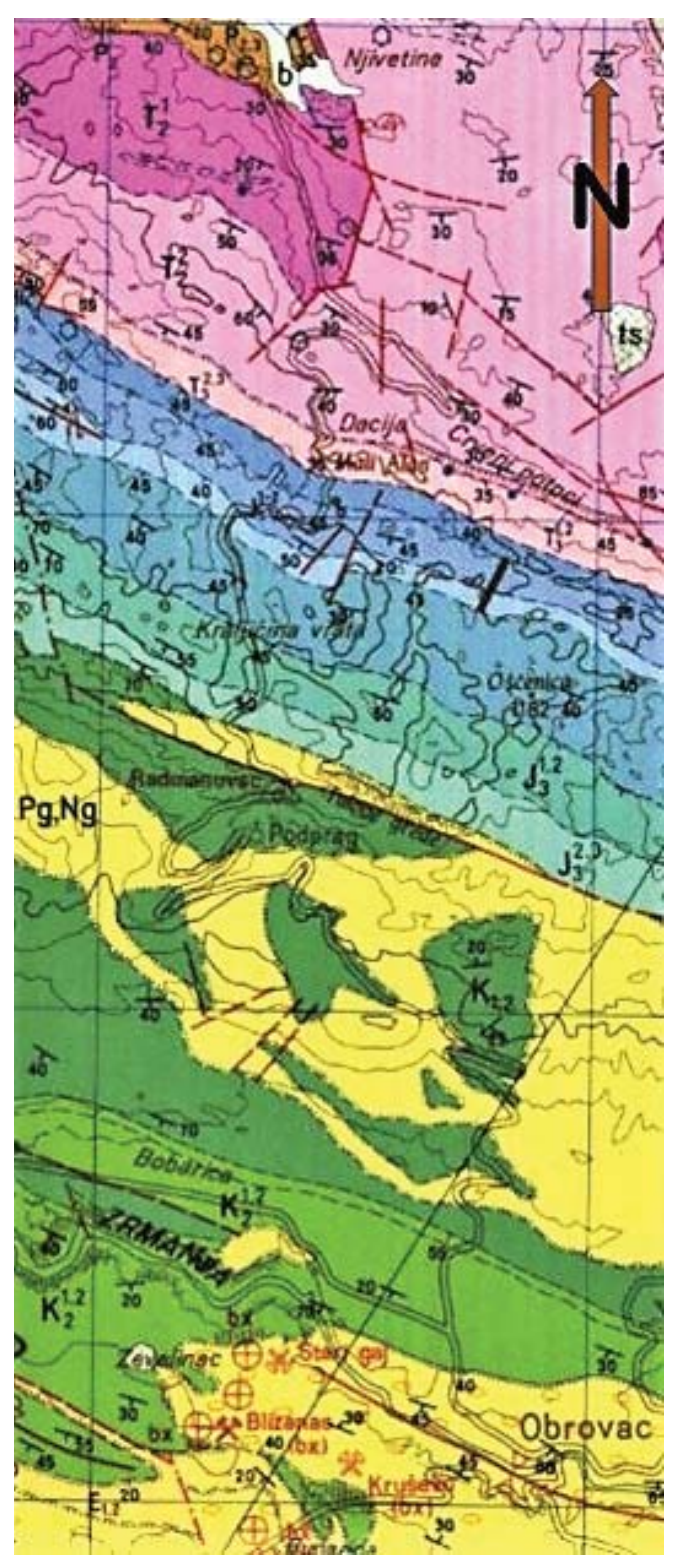

Figure 5: Geology of the larger part of Majstorska Cesta, from Egeljac in Sv. Rok, crossing the Velebit Mt., toward Obrovac; shown on the Basic Geological Map of SFRY 1:100ooo, sheet Obrovac (Ivanović et al., 1973)

stones and Spotted Limestones, Sokač (2007b) Upper Jurassic Limestones, and Velić et al. (2007) Oligocene - Miocene Jelar Breccia (i.e. Velebit Breccia). One of the more recent papers (Velić, 2010) presents a short description of Velebit Mt. geology. This paper describes the entire road section, with an emphasis on geological showpieces.

\section{Results}

Majstorska Cesta is described from the older toward the younger stratigraphic units, starting with the Sv. Rok locality, across Velebit Mt., towards Obrovac. At the start, from Paljenik to the centre of Sv. Rok, the road was first laid on the proluvial Quaternary deposits, and sporadically on the Carboniferous shales and sandstones and on the Lower Triassic micaceous sandstones.

In the majority of Sv. Rok, the road was built over the Middle Triassic Diplopora Limestones, and, near Šlentić, on the Permian Mizzia Dolomites (see Figure 6). Further, up until Egeljac, it is positioned on the alluvial deposits between the Diplopora Limestones and the Mizzia Dolomites.

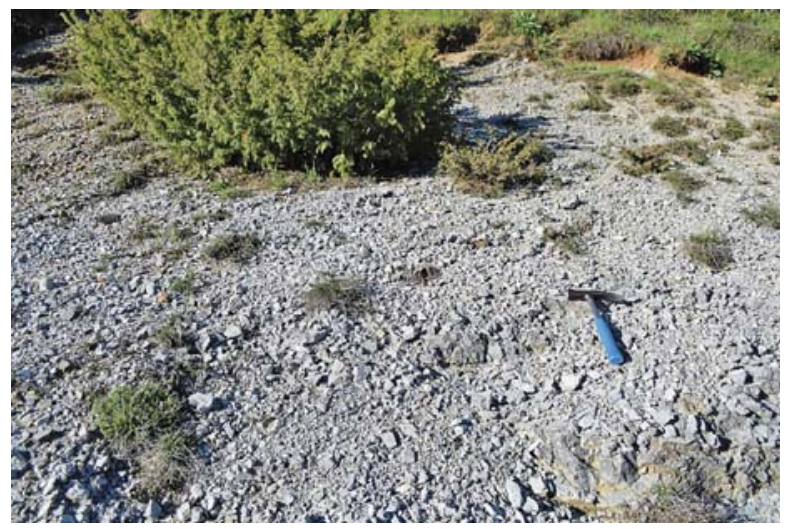

Figure 6: Upper Permian Mizzia Dolomite on the peak above road bend from Šulentić to Egeljac (scale - geological hammer is $31 \mathrm{~cm}$ long); very rich in microfossils - calcareous algae, the most important is famous species Mizzia velebitana (described in the Permian of the Velika Paklenica) and fusulinid foraminifera

On the northern slope of Velebit Mt., from Egeljac to Dacija, the road lies over the Middle Triassic, grey, marble-like, massive and karstified Anisian Diplopora Limestones, until halfway towards Crveni potoci (see Figure 5). Near the hill 852 and at the sharp bend, on the NE side of Siljci Ridge, is a branch of the forest path into the geologically remarkable location Crveni potoci, about $600 \mathrm{~m}$ away. There is an open erosional contact between the Middle and Upper Triassic deposits, about $2 \mathrm{~km}$ long. Karstified grey Diplopora Limestones of Ladinian age have been deposited in subtidal zone and overlain by brownish Raibl Clastics, dominantly siltites with sandstone and scarce conglomerate intercalations. These are terrestrial sediments, painting the nearby Crveni potoci (=Red Creeks) into a brownish-red colour (see Figures 7 and 8). Overlying, Upper Triassic, grey and brown Main dolomites, were deposited at the wide-spread tidal flat plains of the Tethys Ocean. Majstorska Cesta is, from the extension towards Crveni potoci and further into Dacija over a span of $3 \mathrm{~km}$, still built over the Diplopora Limestones on the N slope of Šiljci Ridge (see Figure 9), all over the next eastern extension in the forest. From that crossroad to Mali Alan Pass, the road is located on the Upper Triassic Main Dolomite (see Figure 10), reaching the boundary between the Triassic and Jurassic deposits (see Figure 11). 


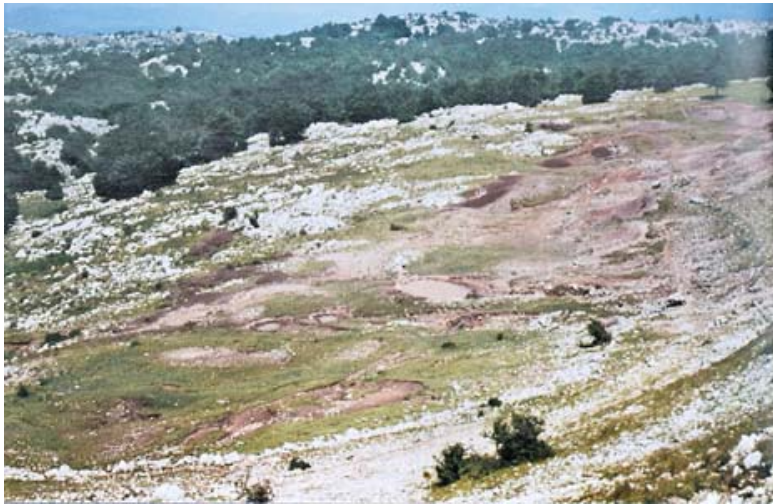

Figure 7: The boundary between the Middle and Upper Triassic deposits on the $\mathrm{W}$ part of Crveni potoci: Middle Triassic Diplopora Limestones (upper part), continental red Raibl siltstones and sandstones with lenses of conglomerates (middle part) and Upper Triassic Main Dolomite (lower part)

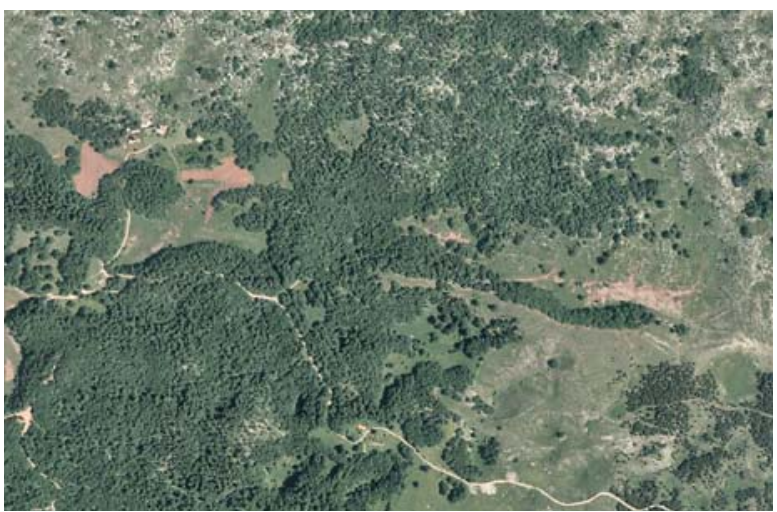

Figure 8: Satellite image (Arkod) of the Crveni Potoci (=Red Creeks) and Bađek areas. Red soil produced by the weathering of the reddish Raibl siltites and sandstones is visible in the centre of the right part of the photo

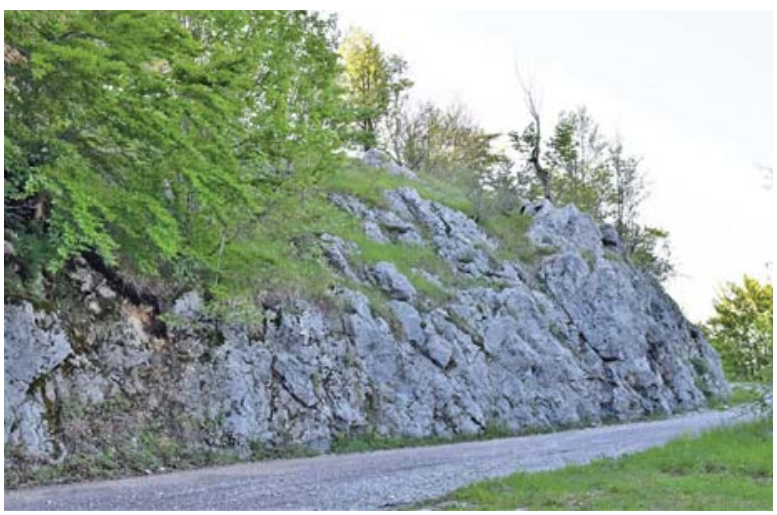

Figure 9: Middle Triassic, Ladinian Diplopora Limestones at the section of Majstorska Cesta on Velebit Mt. (N slopes, at Šiljci Ridge)

The road now reaches the locus typicus of the Lower Jurassic deposits - the Mali Alan Limestones and Dolomites (see Figure 12), which extend towards the shep-

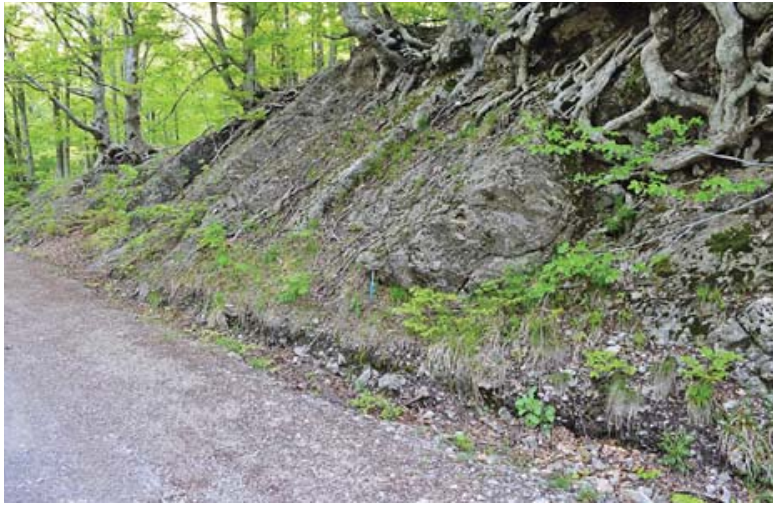

Figure 10: The Main Dolomite strata with a thickness of 30 - $110 \mathrm{~cm}$ in the cutting of Majstorska Cesta, on the N slope of the Mali Alan Pass (scale - geological hammer is $31 \mathrm{~cm}$ long)

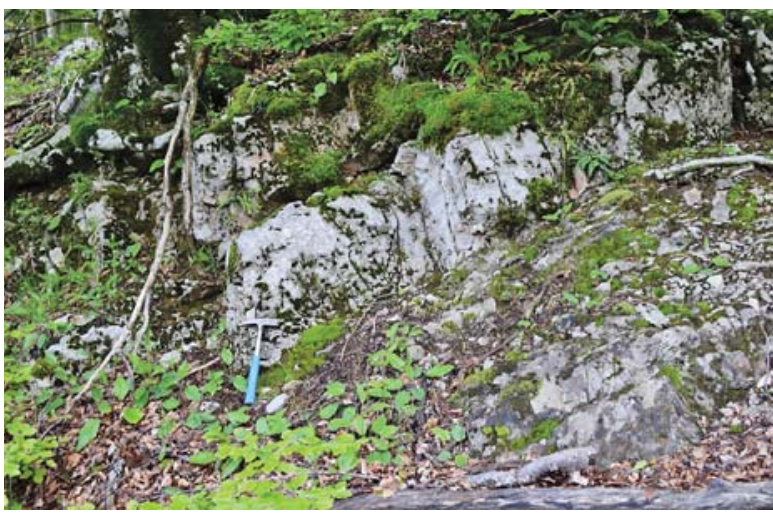

Figure 11: The Triassic - Jurassic boundary: the Triassic gray-brownish Main Dolomite is overlain by the bright layer of the Lower Jurassic limestone of the Mali Alan Unit (scale - geological hammer is $31 \mathrm{~cm}$ long)

herds' settlements. The road then continues through the Lithiotis limestones, and bends towards the $\mathrm{W}$, where there is a viewpoint over the Alan Depression. Here, the road is almost parallel with the strike of the Lower Jurassic limestones, with sedimentological textures visible on upper surfaces, like ripple marks (see Figure 13) and desiccation cracks (see Figure 14), along with the Lithiotid coquinas (see Figure 15).

At the hill 105 and the abandoned quarry of the Lithiotis Limestones (see Figure 20) a boundary between the Lithiotis and Spotted Limestones and Dolomites (see Figure 16) is visible. The road continues towards the $S$ for about $2 \mathrm{~km}$.

After $150 \mathrm{~m}$, on the Spotted Limestone (see Figure 17) the road reached the Middle Jurassic Alan limestones (see Figures 18 and 19), with rare intercalations of brownish dolomites (see Figure 20). The limestones are mostly thick-bedded and highly karstified (see Figure 21), grey mudstones. At Kraljičina Vrata (= Queen's Doors) point, in the road notch, a recumbent anticline 


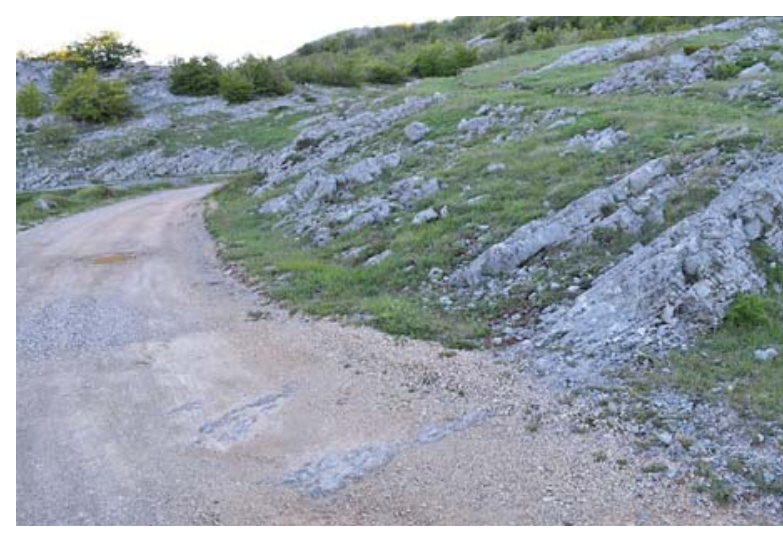

Figure 12: Locus typicus of the lithostratigraphic unit Mali Alan Limestones and Dolomites on Mali Alan Pass: an alteration of greyish limestones and brownish, late diagenetic dolomites; limestones are rich in remains of the fossil calcareous algae, mostly of the genus

Palaeodasycladus; strata thicknesses vary from 30 to $60 \mathrm{~cm}$

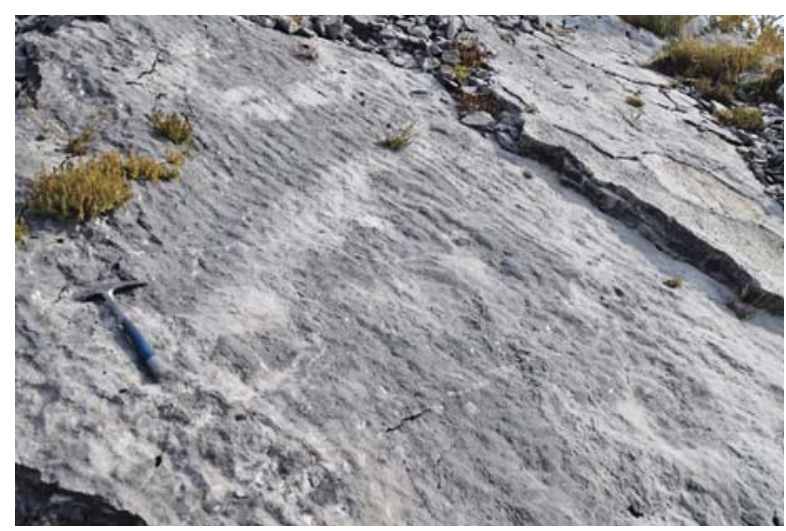

Figure 13: Wave ripples - ripple marks on the Lower Jurassic strata of the Mali Alan Limestone at the Majstorska Cesta towards the abandoned quarry (scale - geological hammer is $31 \mathrm{~cm}$ long)

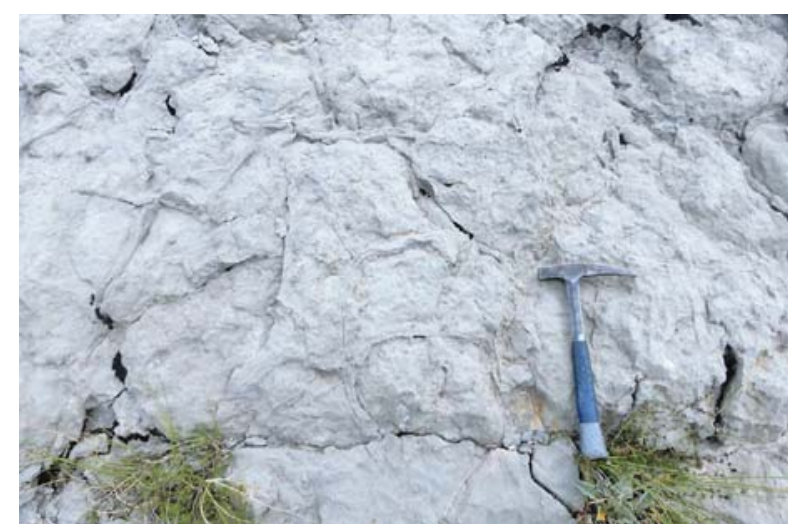

Figure 14: Desiccation cracks on the bedding surface of the Mali Alan Limestone unit along Majstorska Cesta near the abandoned quarry (scale - geological hammer is $31 \mathrm{~cm}$ long)

occurs (see Figure 22), probably representing a synsedimentary sliding structure - slump.

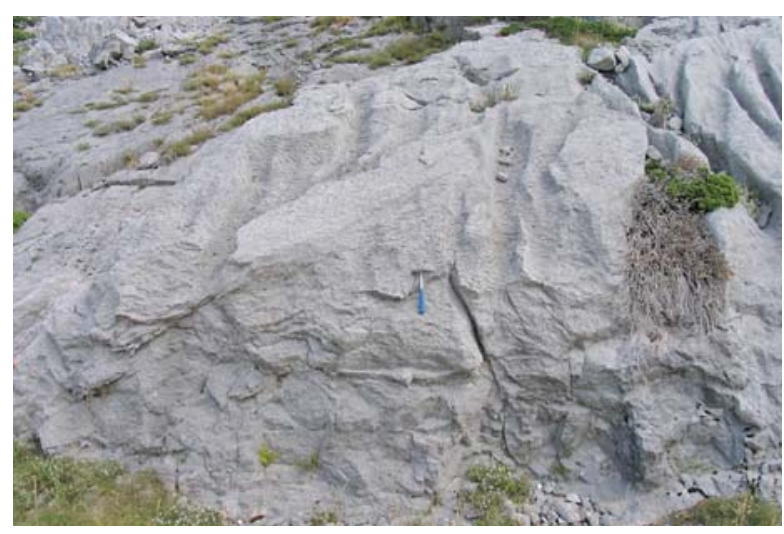

Figure 15: Lithiotid coquina - a bed built up of Lithiotid shells (similar to the contemporary fan mussel Pinna nobilis), broken by the sea currents or storm waves from their living spaces and transported into the protected, calm environment; the photo was taken from the entrance of the abandoned quarry in Lithiotid Limestones; beds without shells contain numerous remains of the Lower Jurassic foraminiferal genera Orbitopsella and Lituosepta

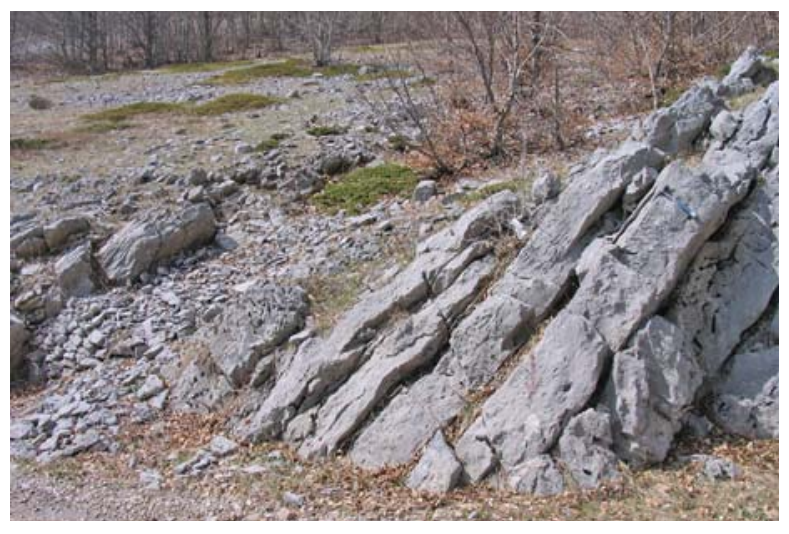

Figure 16: Geological boundary within the Lower Jurassic carbonates between Lithiotid Limestone and Spotted Limestone and a complex texture of the bed of a Lithiotid Limestone bed (with a geological hammer, $33 \mathrm{~cm}$ long): the lower part - transported Lithiotid shells,

the middle part - Lithiotid shells in living positions - very rare findings;

the upper part - again relocated Lithiotid shells

Majstorska Cesta has been cut into by the Alan limestones up to a point $200 \mathrm{~m} \mathrm{~S}$ from Kraljičina vrata, where the boundary of the Middle and Upper Jurassic is exposed (see Figure 23), i.e. between the Middle Jurassic Alan Limestones and the Upper Jurassic Alanac Limestones and Dolomites. Alanac Limestones are very fossiliferous, comprising the abundant foraminiferal tests of genera Andersenolina and Chablaisia, located at hairpin-bends and all over the SI slope of the Kuće Marunića Ridge. There is contact with younger, Upper Jurassic, Clypeina Limestones, which spread toward Tulove Grede locality. On their N slope, there is a large sinkhole, created by the destruction of the subsurface cave roof. From the top, the valley Jurkovića Vrti is composed 


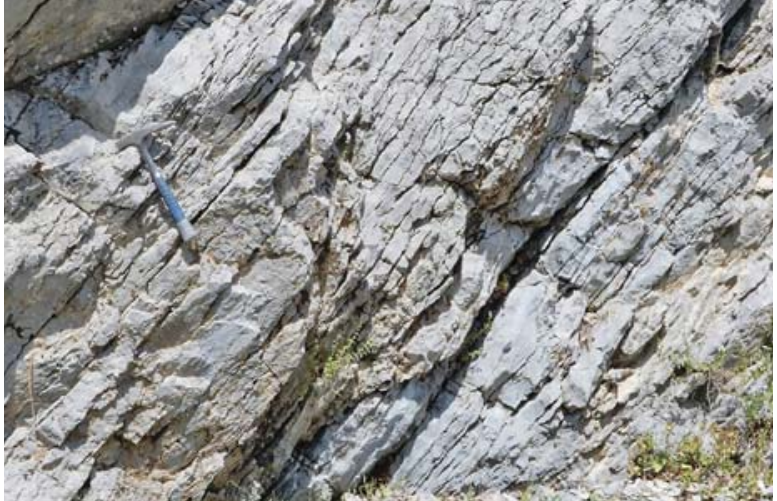

Figure 17: Toarcian Spotted Limestone with a well visible thin bedded pattern of the deeper sea environments; location about $50 \mathrm{~m} \mathrm{~S}$ from the abandoned quarry and elevation point of $1005 \mathrm{~m}$ (scale - geological hammer is 33 cm long)

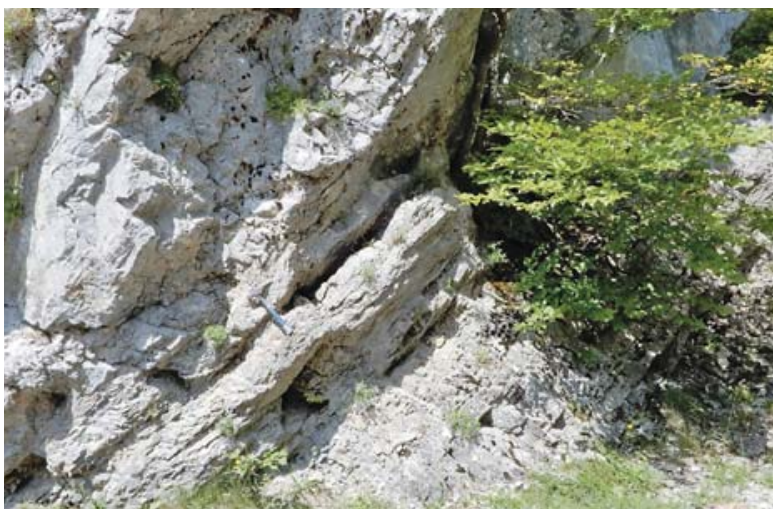

Figure 18: The boundary between the Lower and Middle Jurassic carbonates (marked by a geological hammer): the topmost part of the Lower Jurassic deposits is composed of thin-bedded brownish dolomite of the Spotted Limestone Unit. The base of the Middle Jurassic deposits is represented with dark-greyish, thick bedded limestones of the lithostratigraphic unit Lower Alan Limestones and Dolomites

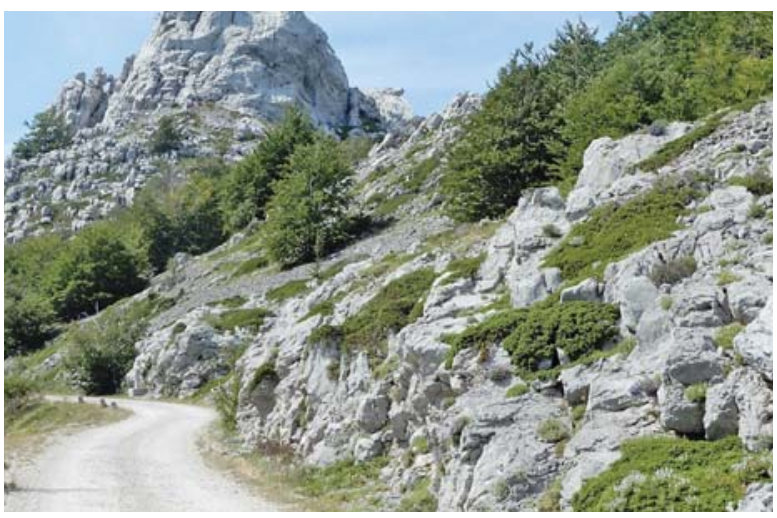

Figure 19: Karstified and fissured dark-greyish and greyish, thick-bedded Middle Jurassic carbonates of the lithostratigraphic unit Lower Alan Limestones and Dolomites

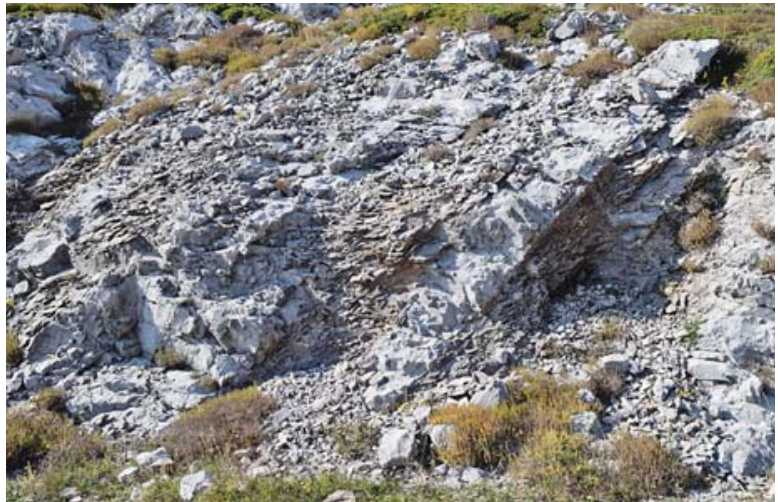

Figure 20: Alteration of greyish limestones and brownish dolomites, lithostratigraphic unit the Lower Alan Limestones and Dolomites

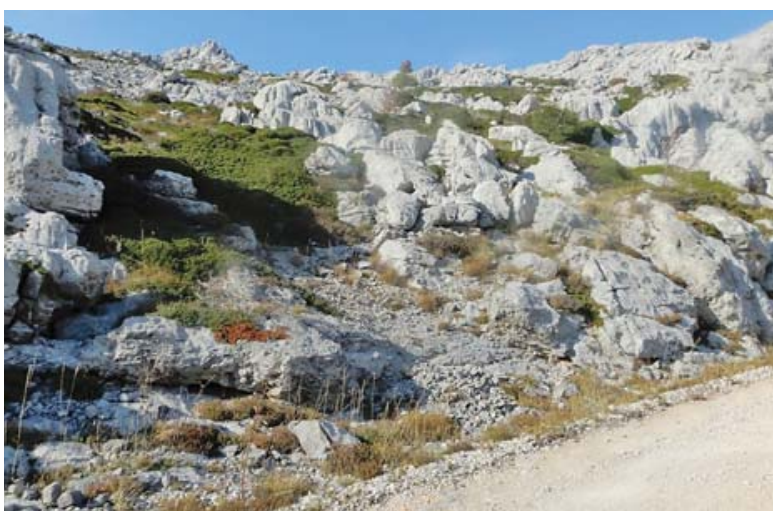

Figure 21: Weathered massive Upper Alan Limestones

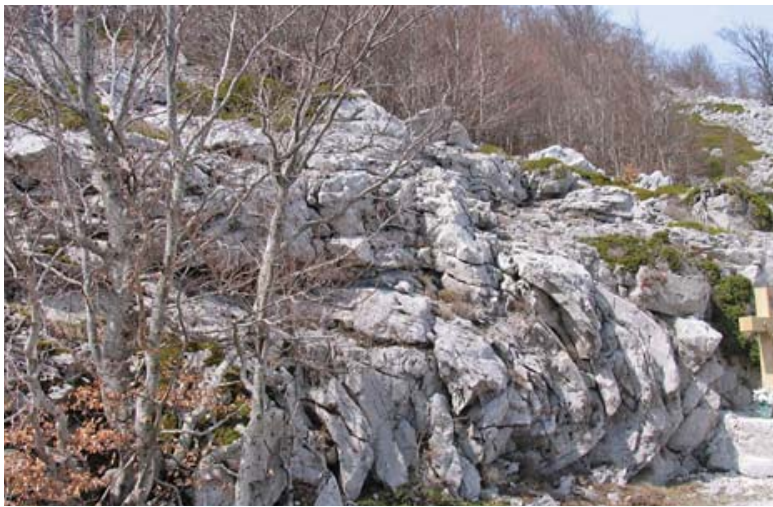

Figure 22: Recumbent fold in the Middle Jurassic Upper Alan Limestones as a result of slumping (not tectonics) during the deposition on a subtidal slope, where calcareous detritus was deposited and reached the critical weight for the gravitational transport and folding of strata

of Upper Jurassic Alanac and Clypeina limestones (see Figure 24).

The Tulove Grede complex represents a remarkable geomorphological landscape of Velebit Mt. They are built of the Velebit Breccia arranged in several rows of 


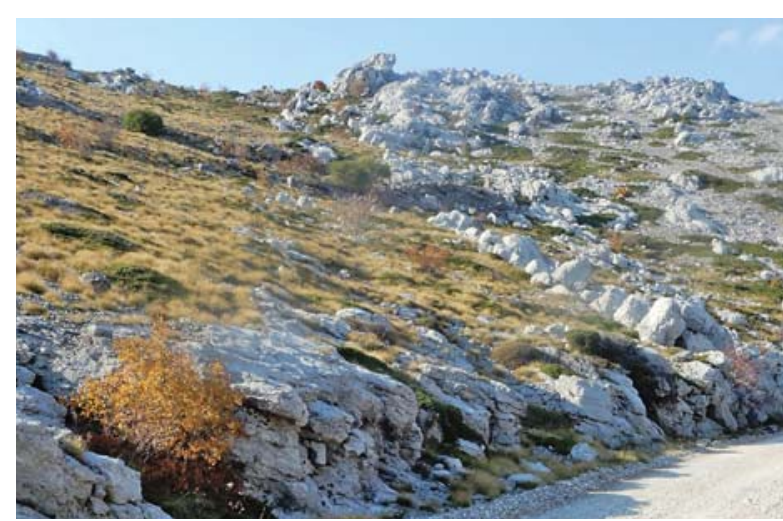

Figure 23: The boundary Middle - Upper Jurassic between the Middle Jurassic Upper Alan Limestones (karst relief on the right part) with the Upper Jurassic Alanac Limestones (flattened slope with grass on the left)

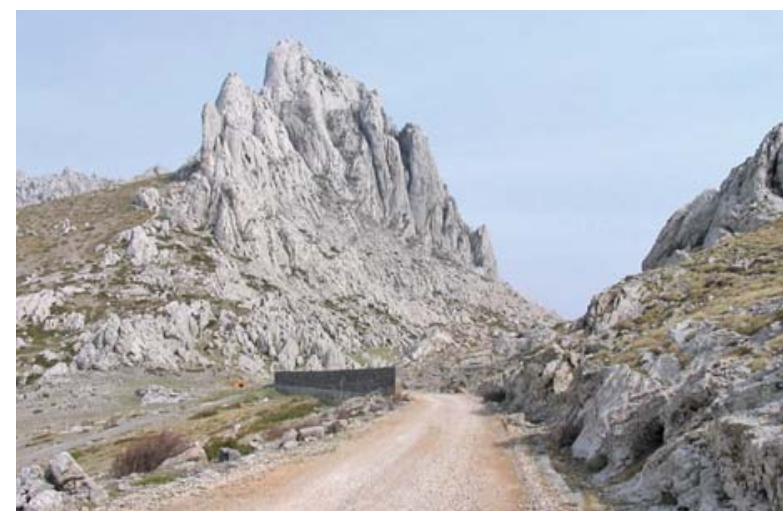

Figure 24: Majstorska Cesta from Nekić to Tulove Grede is built over the Upper Jurassic Clypeina Limestones with intercalations of brownish late diagenetic dolomites

carbonate panels and columns. Majstorska Cesta is cut into the breccia on the $\mathrm{W}$ side of Tulove Grede Ridge.

Majstorska Cesta, from Tulove Grede to Zaton Plain, passes mostly through Velebit Breccia (see Figure 25), occasionally through the Lower Cretaceous limestones (see Figure 26). Before the crossing with the Obrovac

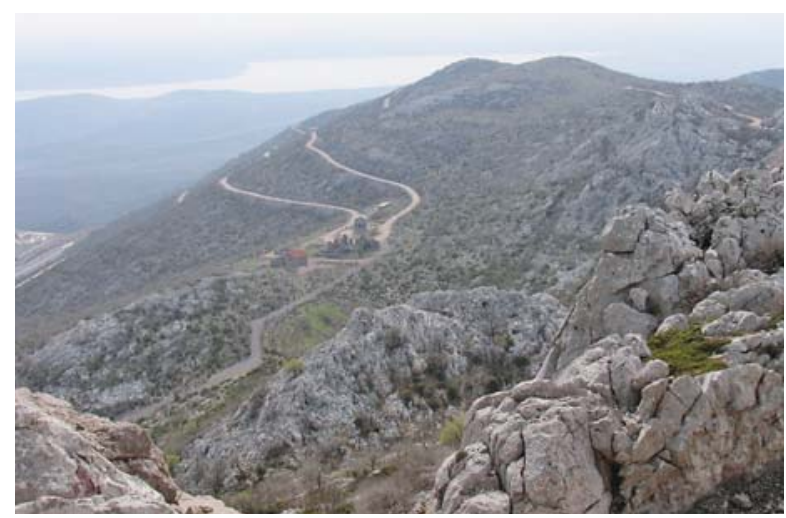

Figure 25: Majstorska Cesta W and SW of Tulove Grede was built up on the Velebit Breccia

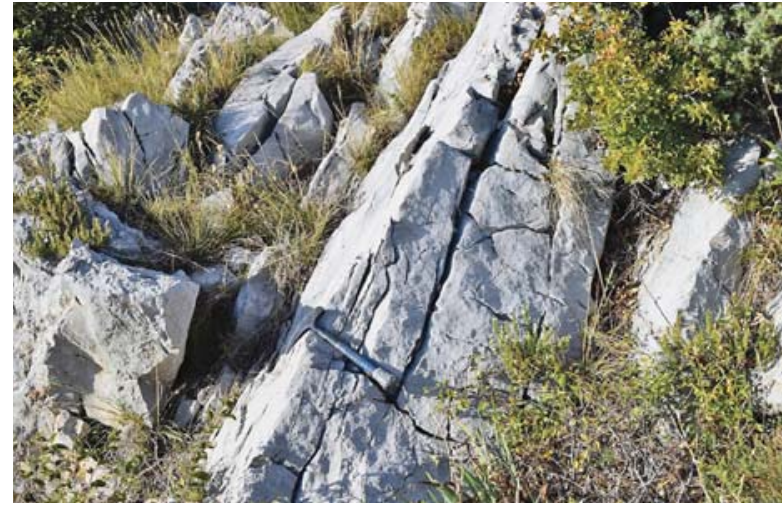

Figure 26: Lower Cretaceous limestones outcropped by Majstorska Cesta, in the base of the Velebit Breccia in the Meki Doci locality (scale - geological hammer is $31 \mathrm{~cm}$ long)

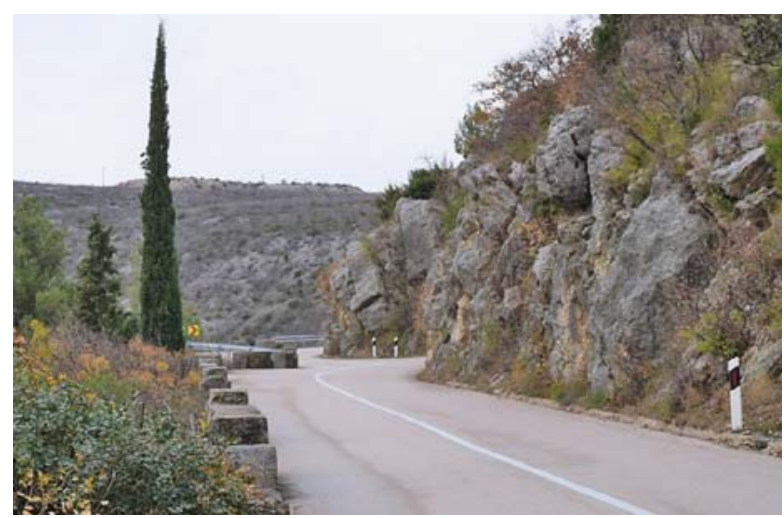

Figure 27: Majstorska Cesta in the Zrmanja River Canyon near Obrovac, cut in by the thick conglomerate strata of the Palaeogene Promina deposits

roundabout, the road leaves the breccia and runs through the Lower Cretaceous limestones. The roundabout gives the best view of Tulove Grede and the S slope of Velebit Mt. where the road passes. At the very end, the road reaches the former alumina factory, where it passes over the Vrakon dolomites and dolomitic breccia and the Upper Cretaceous rudist limestones. The road ends at the bridge over Zrmanja River in Obrovac, in Promina conglomerates and sandstones (see Figure 27) with intercalations of marlstones.

\section{Conclusion}

The main geological values of Majstorska Cesta are:

- it is cut through the Younger Palaeozoic, Mesozoic and Cainozoic rocks, typical for the whole Karst Dinarides;

- Palaeozoic Carboniferous rocks in Sv. Rok and the surrounding areas, represent the basement of carbonate succession of the Karst Dinarides with a thickness of 5000-12000 m; only in the Lika foot- 
hills of Velebit Mt. they are found in continuity with the younger rocks;

- Most of the rock types present along the road are rich in fossil content;

- part of the road, through the Alan Depression, from Mali Alan Pass to Tulove Grede Ridge, is the locus typicus of Jurassic shallow marine carbonate deposits for the entire Karst Dinarides;

- rocks along the road were presented on many geological excursions, from student's fieldtrips to large domestic and international geological meetings;

- the road has been studied in numerous scientific papers, reports, projects, graduate, master and doctoral thesis;

- detailed geoscientists' research along the road made the construction of the Sv. Rok Tunnel possible, on the A1 Highway (with a margin error of strata positions of less than $1 \mathrm{~m}$ ).

- the road was, and always will be an attractive location for scholar, student and scientific fieldtrips, as well as for guided sightseeing tours.

\section{Acknowledgments}

The authors are grateful to Tomislav Malvić, full professor (University of Zagreb-Faculty of Mining, Geology and Petroleum Engineering support: "Mathematical Research in Geology IV."), for professional support. Our thanks goes to anonymous reviewers as well, for their suggestions in both versions of the manuscript. They inspired us to present the obtained data in a more appropriate form and greatly improved the manuscript.

\section{References}

Cernički, L \& Forenbaher, S. (2016): Starim cestama preko Velebita. Libricon d.o.o., Zagreb, 227 p.

Grgasović, T. (2007): The Sv. Rok-Mali Alan Road - Ladinian limestones with Diplopora annulata/Kantia dolomitica. In: Grgasović, T. \& Vlahović, I. (Eds.): 9th International Symposium on Fossil Algae - Croatia 2007, Field Trip Guidebook and Abstracts, Hrvatski geološki institut (Croatian Geological Survey), Zagreb, 29-31.

Grgasović, T. \& Sokač, B. (2007): Sv. Rok - Permian Mizziadolomite.- In: Grgasović, T. \& Vlahović, I. (Eds.): 9th International Symposium on Fossil Algae, Croatia 2007, Field Trip Guidebook and Abstracts, Hrv. geol. institut (Croatian Geological Survey), Zagreb, 7-11.

Grgasović, T. \& Vlahović, I. (2007 eds.): $9^{\text {th }}$ International sysmposium on fossil algae, Croatia 2007., Field trip and abstracts. Hrvatski geološki institut - Croatian geological survey, I-V+1-261, Zagreb.

Ivanović, A., Sakač, K., Marković, S., Sokač, B., Šušnjar, M., Nikler, L. \& Šušnjara, A. (1973): Osnovna geološka karta SFRJ, list Obrovac 1:100 000, L 33-140. Institut za geološka istraživanja Zagreb, Savezni. Geološki zavod Beograd.
Ivanović, A., Sakač, K., Sokač, B., Vrsalović-Carević, I. \& Zupanić, J. (1976): Osnovna geološka karta SFRJ, Tumač za list Obrovac 1:100 000, L 33-140. Inst. geol. istr. Zagreb, Sav. geol. zavod, 1-61, Beograd.

Jelaska, V. \& Velić, I. (1971): Stratigrafija jure južnog Velebita. (General stratigraphic review of Jurassic of the southern Velebit). Nafta, 22, 4-5, 485-495, Zagreb

Koch, F. (1909a): Geologijska prijegledna karta Kraljevine Hrvatske i Slavonije .Medak i Sv. Rok, 1:75 000. Izdanje Kr. hrv. slavon.dalm. zemalj. vlade Odjela za unutarnje poslove, Zagreb.

Koch, F. (1909b): Geologijska prijegledna karta Kraljevine Hrvatske i Slavonije. Tumač geologijske karte Medak Sv. Rok, 1:75 000.- Nakl. Kralj. zemalj. vlade, Odjela za unurarnje poslove, Izdanje Geol. povj.7, 1-31, 5 profila, Zagreb.

Nikler, L. \& Sokač, B. (1968): Biostratigraphy of the Jurassic of Velebit (Croatia)(Biostratigrafija jure Velebita). Geološki vjesnik, 21, Zagreb.

Schubert, R. I. (1909a): Geologija Dalmacije (preveo F. Koch).- Matica dalmatinska, 18 str., Zadar.

Schubert, R. I. (1909b): Geologische Spezialkarte der im Reichsrate vertretenen Königreiche und Länder der Österr.Ungar. Monarchie neu aufgenommen und herausgegeben durch die k. k. Geologische Reichsanstalt. Medak und Sv. Rok 1:75.000.- Geol. Reichsanst. Wien.

Schubert, R. I. (1910): Erläuterungen zur Geologischen Karte der im Reichsrate vertretenen Königreiche und Länder der Österr.-Ungar. Monarchie SW-Gruppe Nr. 116, MedakSv. Rok.- Geol. Reichsanst. Wien, 1-32.

Sokač, B., Šušnjar, M., Bukovac, J. \& Bahun, S. (1976): Osnovna geološka karta SFRJ, Tumač za list Udbina 1:100 000, L 33-128. Institut za geološka istraživanja Zagreb, Savezni. Geološki zavod Beograd, 1-62.

Sokač, B. (2007a): Mali Alan Pass - Lower Jurassic with Palaeodasycladus. - In:Grgasović, T. \& Vlahović, I. (Eds.): 9th International Symposium on Fossil Algae - Croatia 2007, Field Trip Guidebook and Abstracts, Hrvatski geološki institut (Croatian Geological Survey), Zagreb, 33-45.

Sokač, B. (2007b): Limestones of the lower part of the Upper Jurassic with Salpingoporella sellii. 9th International Symposium on Fossil Algae - Croatia 2007, Field Trip Guidebook and Abstracts, Hrvatski geološki institut (Croatian Geological Survey), Zagreb, p 53.

Šušnjar, M., Sokač, B., Bahun,S., Bukovac, J., Nikler, L. \& Ivanović, A. (1973): Osnovna geološka karta SFRJ, list Udbina 1:100 000, L 33-128. Institut za geološka istraživanja Zagreb, Savezni. Geološki zavod Beograd.

Velić, I.(2007a): Velebit Mt. - In: Grgasović, T. \& Vlahović, I. (Eds.): 9th International Symposium on Fossil Algae Croatia 2007, Field Trip Guidebook and Abstracts, Hrvatski geološki institut (Croatian Geological Survey), Zagreb, 7-11.

Velić, I.(2007b): Lower Jurassic Orbitopsella limestone. -In: Grgasović, T. \& Vlahović, I. (Eds.): 9th International Symposium on Fossil Algae - Croatia 2007, Field Trip Guide- 
book and Abstracts, Hrvatski geološki institut (Croatian Geological Survey), Zagreb, 47-49.

Velić, I. (2007c): Lower Jurassic: Domerian 'Lithiotis limestones' and Toarcian 'Spotty limestones'. -In: Grgasović, T. \& Vlahović, I. (Eds.): 9th International Symposium on Fossil Algae - Croatia 2007, Field Trip Guidebook and Abstracts, Hrvatski geološki institut (Croatian Geological Survey), Zagreb, 51-52.

Velić, I., Vlahović, I., Tišljar, J. \& Matičec, D. (2007): Oligocene-Miocene Jelar breccia. - In: Grgasović, T. \& Vlahović, I. (Eds.): 9th International Symposium on Fossil Algae - Croatia 2007, Field Trip Guidebook and Abstracts,
Hrvatski geološki institut (Croatian Geological Survey), Zagreb, 57-58

Velić, I. (2010): Velebit - cesta Sv. Rok - Mali Alan - Tulove grede: evolucija karbonatne platforme i stratigrafija (perm, trijas, jura i "Jelar-naslage"), Kratki prikaz geologije Velebita. U: Horvat, M. (ur.): Vodič ekskurzija, 4. Hrvatski geološki kongres Šibenik, 14-15.10.2010., Hrvatski geološki institut Zagreb, 102-106.

Vlahović, I., Tišljar, J., Velić, I. \& Matičec, D. (2005): Evolution of the Adriatic Carbonate Platform: Palaeogeography, main events and depositional dynamics. Palaeogeography, palaeoclimatology, palaeoecology, 220 (3-4), 333-360.

\section{Author Contributions}

Ivo Velić: conceptualization, investigation, led the research and selected the fields for analyses, prepared the regional geology presentation and connected them with regional geology, writing-original draft. Josipa Velić: visualization, collected field data, writing - review \& editing.

\section{Funding}

This research (analyses) was supported with the project Mathematical methods in geology IV" (led by T. Malvić). Funds were given from the University of Zagreb, Faculty of Mining, Geology and Petroleum Engineering, for the 2019 year.

\section{Conflicts of Interest}

The authors declare no conflict of interest. 